\title{
Немачке библиотеке након Другог светског рата: посебан осврт на импликације уједињења две немачке државе 1990. године
}

\author{
Милица Антић \\ antic.milica18@gmail.com
}

\begin{abstract}
Сажетак
Након пораза у Другом светском рату Немачка је подељена на Савезну Републику Немачку и Немачку Демократску Републику. Библиотеке у овим државама развијале су се под различитим политичким утицајима. У Савезној Републици Немачкој био је заступљен модел америчког библиотекарства, који је у свет немачких библиотека унео три иновације - слободан приступ књигама, референсне услуге и демократију. За то време у Немачкој Демократској Републици библиотеке су биле оружје за едуковање становништва о добробити социјализма. После уједињења две државе 1990. године, приступило се убрзаном интегрисању источнонемачких библиотека у модерно немачко библиотекарство, што је подразумевало куповину и замену опреме, реконструкцију и изградњу зграда за библиотеке и набавку савремене литературе. Данас Немачка има три националне библиотеке - Немачку библиотеку, која је физички раздвојена и налази се у Лајпцигу и Франкфурту на Мајни, Државну библиотеку - Пруско културно наслеђе у Берлину и Баварску државну библиотеку у Минхену, док ефикасну и децентрализовану библиотечку мрежу чини више од 11.000 библиотека.
\end{abstract}

Кључне речи: библиотекарство, Савезна Република Немачка, Немачка Демократска Република, националне библиотеке, библиотечка удружења, библиотечки фонд, ратна разарања, библиотечка опрема, зграде библиотека

\begin{abstract}
Увод
Историја немачког библиотекарства започиње у средњем веку, још за време каролиншке ренесансе, када је забележено постојање првих библиотека у манастирима Фулда, Лорш, Рајхенау и другим. Прикупљајући најсавременију научну литературу, библиотеке су развој људске свести и ума пратиле у стопу, те се у 14. веку јављају и универзитетске библиотеке. На самом крају 19. века сачињена су и Пруска правила за каталогизацију као јасан показатељ да је библиотекарство у овој земљи још тада било развијено и да му се приступало са пажњом. За време Вајмарске републике ${ }^{1}$ уочљив је велики ентузијазам за оснивање и подршку јавних библиотека, али су инфлација и политичке недаће све то учиниле немогућим. У наредним годинама успостављен је нацистички режим и формиран је Трећи рајх, ${ }^{2}$ чија ће схватања и политика умногоме променити судбину библиотека. Моћ нацистичког режима показала се неприкосновеном 10. маја 1933. године када је у Берлину спаљено око 25.000 књига, како би у пламену нестало све оно што није било у немачком духу. Истог дана широм земље горело је на хиљаде књига на универзитетима, а претворена у пепео нашла су се дела јеврејских, комунистичких, марксистичких и пацифистичких аутора попут Карла Маркса, Фридриха Енгелса,
\end{abstract}

\footnotetext{
1 Вајмарска република настала је након Првог светског рата укидањем немачке монархије. Име је добила по граду Вајмару, а постојала је од 1919. до 1933. године.

2 Трећи рајх представља Немачку у периоду од 1933. до 1945. године која је била под влашћу нацистичке партије са Адолфом Хитлером као државним вођом.
} 
Лава Троцког, Ериха Кестнера и других. Сто година пре овог догађаја Хајнрих Хајне забележио је своју мисао: „Тамо где се пале књиге, на крају ће се спаљивати и људи” и заиста, 10. мај 1933. године представљао је увертиру за све предстојеће догађаје. У периоду од 1933. до 1939. године нацистички режим успео је да трансформише библиотеке од мирних, тихих упоришта знања у места за активну пропаганду нацистичких идеја. Како би се идеје што ефикасније спроводиле оснивале су се библиотеке у свим селима са 500 или више становника, а њихове полице биле су попуњене литературом прожетом фашистичком идеологијом. Метафорички речено, библиотеке су пре 1933. године биле под дебелим слојем прашине коју је нацистичка идеологија својим фанатизмом одувала и том приликом унела нове вредности, да би се све на крају завршило уништењем великог броја библиотека и фондова. „Библиотекарство, као и многе друге области у немачком друштву, представљало је парадоксалну комбинацију строгих правила, попут цензуре и напада на црквене библиотеке, и слободе која је приморавала библиотекаре да се понашају независно када је комуникација постала отежана, а многи споразуми прекршени". ${ }^{3}$ Ипак у годинама које следе, Немачка је успела да преброди све губитке проузроковане поразом у Другом светском рату и да данас са својим библиотекама постане одличан пример успешног пословања.

„Погођена катастрофом каквој у читавој њеној историји није било равне, са својим великим градовима збрисаним са земље, са индустријом коју су бомбардовања, додуше, делимично поштедела, али која је била паралисана немогућношћу транспорта, налазећи се под окупацијом четирију великих сила, лишена властитог новца и приморана на трампу, Немачка је постала само објекат светске политике". ${ }^{4}$ Као победнице из Другог светског рата ${ }^{5}$ изашле су четири велике силе - Сједињене Америчке Државе, Велика Британија, Француска и Совјетски Савез, које су Немачку поделиле на четири окупационе зоне. Западне територије су биле под влашћу Сједињених Америчих Држава, Велике Британије и Француске, а источне су биле потчињене совјетској администрацији. До коначне поделе Немачке дошло је 1949. године када су Сједињене Америчке Државе, Велика Британија и Француска ујединиле своје окупационе зоне и формирале Савезну Републику Немачку (СРН). Совјетски Савез, незадовољан овим чином, одлучује да напусти алијансу и формира Немачку Демократску Републику (НДР). Две немачке државе постојале су преко 40 година, а библиотеке у овим земљама биле су посредници различитих политичких убеђења, норми и очекивања онаквих какве су емитовале тадашње власти. Након уједињења 1990. године, библиотеке су још једном морале да истрају како би унапредиле и усагласиле две супротности које су у том тренутку чиниле библиотекарство у земљи.

\section{Немачке библиотеке након Другог светског рата}

Немогуће је прецизно утврдити колики су губици настали у немачким библиотекама након Другог светског рата. По статистичким подацима, оне су поседовале преко 56 милиона књига, а изгубљено је око 15 милиона као директна последица рата. Нако је знатни део драгоценог фонда евакуисан, велики број библиотека је сравњен са земљом, те се укупна штета у немач-

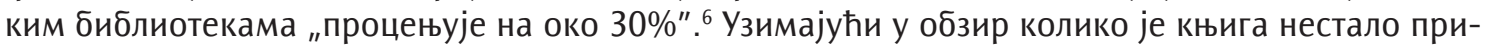
ликом евакуације и неадекватног смештаја, те колико их је уништено пре самог рата, губици

\footnotetext{
3 Margaret Stieg, "The Second World War and the Public Libraries of Nazi Germany", Journal of Contemporary History 1 (January, 1992): 37, http://www.jstor.org/stable/260777 (preuzeto 12. 2. 2017).

${ }_{4}^{4}$ Žak Droz, Istorija Nemačke (Zemun: Biblioteka XX veka; Beograd: Plato, 1999), 101.

5 Други светски рат почео је нападом Немачке на Пољску 1. септембра 1939, а Немачка је потписала капитулацију 2. септембра 1945. године.

${ }^{6}$ Lester K. Born, "The Archives and Libraries of Postwar Germany", The American Historical Review 1 (1950): 36, http://www.jstor.org/ stable/1840620 (preuzeto 10. 11. 2016).
} 
немачких библиотека за 12 година свакако прелазе 15 милиона публикација, што је, на пример, више од половине фонда највеће библиотеке у овој земљи. ${ }^{7}$ Бомбардовања су оштетила 378 библиотека у 72 немачка града, док су делимично оштећење претрпеле библиотеке у 131 граду. „У периоду 1948-1949. године 77\% општина у Немачкој није поседовало јавну библиотеку, а $41 \%$ становиштва живело је у општинама без јавних библиотека". 8

Дошло се до решења да се фонд библиотека које су остале без својих грађевина распореди по накнадно отвореним читаоницама у граду, а таква судбина задесила је Универзитетску библиотеку у Минхену (Die Universitätsbibliothek der LMU München). Цела зграда баварске државне библиотеке била је готово уништена, изузев једног крила, у којем је касније отворена једна читаоница, међутим, највећи део преосталог фонда није био доступан. У Хамбургу су зграде државне и универзитетске библиотеке уништене, а око 70\% њиховог фонда је делом изгорео, а делом је евакуисан на исток Немачке. У савезној држави Баден-Виртемберг Државна библиотека (Württembergische Landesbibliothek) је изгубила сав свој фонд, али су евакуацијом сачуване све инкунабуле. Универзитетска библиотека у Гетингену (Die Niedersächsische Staats-und Universitätsbibliothek Göttingen) је изгубила своју зграду, а од преко милион књига које је поседовала, изгубила је само 63.000, од чега су више од половине били дупликати.

Губици библиотечких колекција настајали су због конфисковања свих публикација које су у себи носиле дух нацистичког режима, а овој акцији се подједнако прибегавало у Савезној Републици Немачкој и у Немачкој Демократској Републици. Било је и пасивних губитака због немогућности прикупљања стране литературе током нацистичког режима и ратног периода, а објављивање дела немачких аутора строго је контролисано, те су многи напуштали земљу како би могли да објављују без цензуре. У послератним годинама библиотеке су још једном постале поприште борбе различитих политичких идеја. Док су у Савезној Републици Немачкој америчке власти покушавале да наметну своју визију демократије уз помоћ специјално опремљених библиотека, са друге стране, у Немачкој Демократској Републици, комунистичка идеологија је одређивала структуру фондова.

Како је након поделе Немачке Национална библиотека у Лајпцигу (Die Deutsche Bücherei in Leipzig) припала НДР, 1946. године у Франкфурту на Мајни формирана је Немачка национална библиотека (Die Deutsche Bibliothek in Frankfurt am Main). Обе библиотеке су имале исту мисију, а то је да израђују националну библиографијуํำ и прикупљају све радове објављене у Немачкој и радове објављене ван њених граница, а који се односе на Немачку и њен народ. Пруска Државна библиотека у Берлину (Staatsbibliothek zu Berlin - Preußischer Kulturbesitz) је током рата готово уништена, док је њен фонд расут на чак 30 локација. „По завршетку Другог светског рата, књижни фонд највеће и најстарије берлинске библиотеке смањио се за чак два милиона библиотечких јединица. Фонд који је преживео рат, подељен је на две стране - источни и западни део". ${ }^{10}$ Део који је усмерен ка западу бројао је око 1,5 милиона јединица грађе и транспортован је у Хесен у библиотеку која је 1946. године отворена за јавност. У периоду од 1964. до 1968. године, ова библиотека, чији је фонд бројао око пет милиона јединица библиотечке грађе, премештена је у Западни Берлин. Потом је 1978. године смештена у улицу Потсдамер, где се и данас налази. Првобитна зграда ове библиотеке, након

\footnotetext{
7 Највећом библиотеком у Немачкој данас се сматра Немачка национална библиотека у Лајпцигу и Франкфурту на Мајни са фондом од око 30 милиона публикација.

8 Margaret Chaplan, "American Ideas in the German Public Libraries: Three Periods", The Library Quarterly: Information, Community, Policy 1 (јануар, 1971): 48, http://www.jstor.org/stable/4306045 (preuzeto 12. 2. 2017).

9 Немачка библиотека у Лајпцигу приликом израде националне библиографије (Deutsche Nationalbibliographie) користила је Библиотечко-библиографску класификацију (Библиотечно-Библиографическая Классификация - ББК). Овај класификациони систем користиле су библиотеке у Совјетском Савезу. Од 1960. до 1968. године објављено је 30 томова приручника за ББК. Људско знање подељено је на 21 дисциплину, а на првом месту је марксизам-лењинизам. Распадом Совјетског Савеза, ова класификација престаје да се користи.

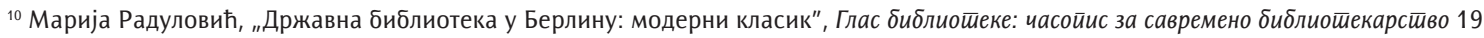
(2012): 106, http://www.cacak-dis.rs/elektronska_izdanja/gb19/101-114-Marija-Radulovic.pdf (преузето 18. 10. 2016).
} 
поделе Берлина 1961. године, нашла се на источној страни града, у совјетској окупационој зони. Упркос тешким оштећењима, отпочела је са радом 1964. године. Три године касније, у ову библиотеку враћено је око 900.000 библиотечких јединица, али је њена централна читаоница постала употребљива тек 1975. године. Представљала је главну академску библиотеку у НДР и, заједно са Националном библиотеком у Лајпцигу, вршила је функцију националне библиотеке.

\section{Библиотеке у Савезној Републици Немачкој}

Након проглашења Савезне Републике Немачке 1949. године прибегло се реконструкцији уништених и оштећених зграда библиотека и обнављању њихових фондова. Библиотеке су на тај начин повећале своје колекције, унапредиле своје функције и услуге и коначно су могле да оформе комплексан, али ефикасан библиотечки систем који би опслуживао растуће потребе за информацијама тада модерног демократског друштва са високим стандардима у области образовања и истраживања. У СРН уложен је огроман труд у измени библиотечког пословања које је било заступљено пре рата. Била је потребна промена у целокупној свести грађана СРН, јер су дубоко укорењени национализам и самонаметнута интелектуална изолација учинили да библиотеке не буду спремне да сарађују.

Моћно средство у промоцији демократских идеја међу немачким народом били су информациони центри које је оснивала влада Сједињених Америчких Држава. Познатији немачком народу као „америчке куће” (Amerika-Häuser), отварани су већ 1945. године, како би Немцима представили модел америчког библиотекарства. Центри су имали колекције са распоном "од 20.000 до 30.000 књига, и били су претплаћени на преко 500 наслова америчких часописа и новина". ${ }^{11}$ Већина књига била је на енглеском, док су тек једну петину чинили преводи дела на немачком језику. Америчко библиотекарство унело је три иновације у свет немачких библиотека - слободан приступ књигама, референсну услугу и постулате демократског уређења друштва. Слободан приступ књигама пружао је прилику Немцима да као корисници библиотека разгледају и прелиставају доступне књиге, те изаберу неколико и однесу кући како би их прочитали. Очекивало се да ће управо слободан приступ књигама имати снажан утицај на развој истинске демократске концепције слободе говора и толеранције према различитим мишљењима о тадашњим политичким, културним, економским и социјалним проблемима и дешавањима. Како су успостављени основни принципи демократизације образовања у Немачкој, чиме се подразумевало да образовање буде свима подједнако доступно, тако је све више људи посећивало библиотеке и долазило у контакт са демократским начелима. Проблем слободног приступа имао је своју физичку страну, која је подразумевала измену структура библиотечких зграда и метафизичку, која се огледала кроз способност корисника да доносе самосталне одлуке приликом избора књига и подразумевала је спремност библиотекара да прихвате ту одлуку без поговора. Посредством референсне услуге библиотекари су морали више да комуницирају са корисницима и ослушкују њихове потребе, али пре свега подразумевало се да су били упознати са фондом библиотеке.

Године 1954. у Западном Берлину, на само километар од границе са источним делом града, као поклон немачком народу од Сједињених Америчких Држава саграђена је Америчка меморијална библиотека (Amerika-Gedenkbibliothek). ${ }^{12}$ Град Берлин донирао је место за изградњу, а немачки библиотекари су имали прилику да сами изаберу почетни фонд који је на дан отварања бројао 100.000 публикација. Ова библиотека унела је још једну новину у немачко

\footnotetext{
${ }^{11}$ Redmond Burke, "German Librarianship from an American Angle", The Library Quarterly: Information, Community, Policy 3 (jyл, 1952 ): 185, http://www.jstor.org/stable/4304131 (preuzeto 12. 2. 2017).

12 Отворена је 17. септембра 1954. године, а са изградњом Берлинског зида 1961. године, ова библиотека постаје примарна јавна библиотека у Западном Берлину. Данас је део Централне државне библиотеке у Берлину (Zentral- und Landesbibliothek Berlin).
} 
библиотекарство, а то је било потпуно бесплатно чланство. У њеним просторијама одржаване су различите културне активности попут јавних читања, дискусија, концерата, предавања, конференција и професионалних састанака. Библиотеке у СРН су полако усвојиле слободу Америчке меморијалне библиотеке, као и њену организацију и технологију, али највише њен дух. Ова библиотека уписана је у историју немачког библиотекарства у правом тренутку, јер су Немци након Другог светског рата тежили не ка развијању предратног модела пословања, већ ка формирању потпуно новог. Идеја Америчке меморијалне библиотеке је, у тренутку њеног оснивања, била сасвим јединствена, док данас овај тип организације пословања и самог приступа корисницима представља стандард за филозофију и праксу модерног библиотекарства.

По статистици броја библиотека и величине њихових фондова из 1958. године следи да је СРН имала „три националне библиотеке са 4.170.000 књига; 25 универзитетских са 12.900.000, не укључујући око 12 милиона књига у библиотекама у склопу института и библиотекама семинара на различитим универзитетима; 264 специјалних библиотека са 13.230.000 књига; 7 школских са 199.000, где су у статистику укључене само оне библиотеке са преко 10.000 публикација, иако је скоро свака школа у држави имала своју школску библиотеку и 10.361 јавних библиотека са 25.500.000 књига".13

\section{Библиотеке у Демократској Републици Немачкој}

Немачка Демократска Република била је организована по систему других комунистичких земаља у Источној Европи. Сходно марксистичко-лењинистичком систему, и у НДР је постојала владајућа партија - Јединствена социјалистичка партија Немачке.

Убрзо након обнављања оштећених зграда библиотека спроведена је акција издвајања и забране фашистичке литературе, а библиотекама се забрањивало да изнајмљују неодобрену социјалну литературу и литературу која је пропагирала демократске врендости. „Истовремено држава је форсирала прихватање лењинистичких принципа". ${ }^{14}$ То је подразумевало да наклоност ка социјалистичким идејама треба да буде главно правило приликом избора литературе, што је од библиотека чинило оружје за едуковање становништва о добробити социјализма. Приступило се стварању централизоване библиотечке мреже како би се ови принципи што ефикасније спроводили. Библиотечка мрежа захтевала је од библиотека да прикупљају материјал у складу са својом величином и функцијама које су дефинисане Библиотечком уредбом Немачке Демократске Републике (Die Bibliotheksverordnung der Deutschen Demokratischen Republik -BVO) донетом 31. маја 1968. године у Берлину. Уредба дефинише да библиотеке треба да „раде на изградњи напредног социјалистичког друштва прикупљањем књига, часописа, музике, аудиовизуелне грађе и литературе из свих области знања и подручја за истраживање, наставу, праксу, образовање и разоноду и на улози посредника између корисника и информација". ${ }^{15}$ Односила се на Немачку државну библиотеку у Берлину, Немачку библиотеку у Лајпцигу, универзитетске, централне, јавне, школске и друге библиотеке. Оне својим методама рада треба да подрже научну и технолошку револуцију и социјалистичку економију и да промовишу научни напредак, те да играју важну улогу у образовном и културном животу и константном напретку образовања становништва. Министарства, шефови централних државних органа и председници савета округа одговорни су за дефинисање принципа за управљање, организацију и садржај библиотека на територијама под њиховом надлежношћу. „Министарство културе одговорно је за развој библиотечког система. Бави се припремама и представљањем одлука у

\footnotetext{
${ }^{13}$ Margaret Chaplan, "Public Librarianship in the Federal Republic of Germany since 1945", The Library Quarterly: Information, Community, Policy 4 (1966): 307, http://www.jstor.org/stable/4305693 (preuzeto 7.11. 2016).

${ }^{14}$ Wayne A. Wiegand, eds., Encyclopedia of Library History (New York: Garland, 1994), 241.

${ }^{15}$ Bibliotheksverband der DDR, Die Bibliotheksverordnung der Deutschen Demokratischen Republik und mit ihr in engem Zusammenhang stehende rechtliche Regelungen und Vereinbarungen (Berlin: Bibliotheksverband der Deutschen Demokratischen Republik, 1980 ), 8.
} 
домену библиотекарства Савету министара, обезбеђује јединствени план активности свих типова библиотека, потврђује формирање централних научних библиотека, а у сарадњи са Министарством за високо образовање и Министарством за науку и технологију доноси планове за реализацију развоја библиотечког система". ${ }^{16}$ Остала поглавља Уредбе дефинишу задатке и функције сваког типа библиотека, изградњу магацина, обуку и образовање библиотекара, сарадњу са другим институцијама и организацију, прикупљање и позајмицу библиотечке грађе. Посебна пажња се придаје избору литературе и приступу деци и младима.

Након оснивања НДР, у овој држави било је 59 научних и 4000 јавних библиотека, од којих је 41 била у Источном Берлину. „Године 1954. централне, матичне библиотеке основане су у свим административним окрузима у НДР како би унапредиле библиотечки систем". ${ }^{17}$ Развој колекција јавних библиотека у НДР контролисао је Централни институт за библиотекарство (Zentralinstitut für Bibliothekswesen). ${ }^{18}$ За мање библиотеке које нису имале довољно простора и новца да прикупљају целокупну издавачку продукцију НДР, овај институт је недељно објављивао листу препоручених публикација. ${ }^{19}$

Власти у НДР су на свим погодним местима оснивале библиотеке, те су се оне могле наћи у затворима, болницама, старачким домовима и фабрикама. У местима где их није било могуће основати, организоване су покретне библиотеке. Толики број библиотека у НДР са својим услугама, фондом, опремом и библиотекарима није пратио савремене трендове у библиотекарству и није обезбеђивао пораст броја читалаца, нити задовољавао њихове жеље и потребе. У годинама након уједињења уследило је затварање мањих библиотека и преуређивање зграда и фондова библиотека у већим градовима.

\section{Немачко библиотекарство након уједињења две немачке државе 1990. године}

Уједињењу Немачке претходила је мирна револуција, у немачком народу познатија као Wende, ${ }^{20}$ која је своју победу крунисала 3. октобра 1990. године, даном када су Савезна Република Немачка и Демократска Република Немачка уједињене. Годину дана пре тога, срушен је Берлински зид, ${ }^{21}$ симбол Хладног рата ${ }^{22}$ и Гвоздене завесе. ${ }^{23}$ Након уједињења, Немачка је морала одолети изазовима који су се јавили на путу постизања складне целине између две државе које су се деценијама уназад развијале „са различитим ставовима, вредностима, веровањима и очекивањима". ${ }^{24}$ Пројекат назван Aufbau Ost (Paзвој Нсйочне Немачке) односио се на развој бивше Немачке Демократске Републике како би услови живота били једнаки онима

\footnotetext{
${ }^{16}$ Ibid., 15.

${ }^{17}$ Heinz Werner, "The Public Libraries in East Berlin", Library Trends 1 (Summer, 1965): 24,

${ }^{h}$ ttps://www.ideals.illinois.edu/bitstream/handle/2142/6230/librarytrendsv14i1e_opt.pdf?sequence=1 (preuzeto 18. 10. 2016).

${ }^{18}$ Институт је био одговоран за пословање свих јавних библиотека на територији НДР. Такође је бринуо о истраживачким студијама на пољу библиотекарства, саветовао је како надоградити и повећати библиотечке магацине и давао је инструкције за објављивање часописа Библиоешекар (Der Bibliothekar)

19 Године 1989. Централни институт за библиотекарство препоручио је око 2500 наслова.

${ }^{20}$ Wende је немачки термин који би се превео као преокрет. Револуција која је названа овим именом трајала је од 9. новембра 1989. до почетка јула 1990. године у циљу поновног уједињења Немачке.

${ }^{21}$ Берлински зид саградила је комунистичка власт 1961. године како би се спречио одлив становника са истока града на слободни запад у потрази за бољим условима живота. Зид је делио Берлин чак 28 година, а његово рушење отпочело је 9. новембра 1989. године које се завршило уједињењем Немачке.

${ }_{22}^{2}$ Хладни рат је назив за отворену нетрпељивост која се након Другог светског рата јавила између Сједињених Америчких Држава и Совјетског Савеза као и између њихових савезника. Иако су се обе стране непрестано наоружавале, рат између ове две силе није избио.

${ }_{23}^{3}$ Метафора „гвоздена завеса" користила се да означи поделе у Европи након Другог светског рата на два дела. Са источне стране налазиле су се земље Источне Европе као и многе земље у Централној Европи које су биле под политичким утицајем Совјетског Савеза. Са западне стране Гвоздене завесе налазиле су се државе Западне и Јужне Европе. Већина њих биле су у НАТО пакту и у савезу са Сједињеним Америчким Државама. Она је симболично делила Европу до 1990. године.

${ }^{24}$ S. Beckers, "Political Culture: Differences in East and West Germany" (master's thesis, Oregon State University, 2007), 17 http://citeseerx.ist.psu.edu/viewdoc/download?doi=10.1.1.595.8724\&rep=rep1\&type=pdf (preuzeto 17. 11. 2016).
} 
у СРН. Као најуспешнија показала се акција реновирања градова Лајпцига, Дрездена, Халеа и Кемница, који су годинама уназад пропадали у НДР. Осим тога, радило се и на изградњи пословних и индустријских објеката, постављању телекомуникационих објеката, увођењу соларне технологије и технологије за заштиту животне средине. Огромни напори уложени су и у заштиту и развој инфраструктуре, у развој туризма и у очување културних добара. Укинута је забрана путовања, здравствена нега је пружана и најсиромашнијим становницима, а радило се и на усавршавању радних способности становника бивше НДР.

Пред уједињење, 1989. године, Немачка Демократска Република „имала је 16.434 .000 становника и 13.545 јавних библиотека ${ }^{25}$ које су укупно имале 51.619 .000 библиотечких јединица. Исте године у НДР било је 769 академских библиотека које су имале колекције од 42.602 .000 јединица грађе". ${ }^{26}$ Такође је постојало „9 универзитетских библиотека са својим 371 огранком који су складиштили укупну колекцију од 20.571.000 библиотечких јединица". ${ }^{27}$ Ови подаци јасно показују предност јавних библиотека у бројности оснивања и величини фондова. Непосредно пред уједињење, НДР је имала око 32.000 библиотека ${ }^{28}$ са колекцијом од 770 милиона јединица библиотечке грађе.

У Савезној Републици Немачкој је у 1989. години постојало „4988 јавних библиотека ${ }^{29} \mathrm{ca}$ колекцијом од 75.575.717 библиотечких јединица. Као контраст НДР, у СРН било је 5605 академских библиотека са укупним фондом од 159.670.000 јединица библиотечке грађе. У истој години у СРН постојало је 60 матичних универзитетских библиотека са фондом од 78.066.000 публикација". ${ }^{30}$ На основу горепоменутих података може се лако закључити да су академске библиотеке биле више вредноване од јавних, те да се њиховом квалитету и повећању фондова са пажњом приступало, што је сасвим различита ситуација од оне у НДР. Немогуће је не запитати се шта је довело до овако различитих приоритета, односно вредновања библиотека у две немачке државе. Одговор лежи у политичком и културном пејзажу који је постојао на истоку и западу. У НДР су јавне библиотеке биле промовисане и постављене испред академских из идеолошких разлога. „Са литературом и специјалним програмима за све грађане, али посебно за децу и младе, јавне библиотеке биле су међу многим културним установама којима је поверено да социјализам одржавају живим у НДР". ${ }^{31}$ Овде долази до разилажења свести о књизи и читању између две Немачке. Године 1992. урађена је студија која се бавила упоређивањем читалачких навика између СРН и НДР. Студије су показале да је бивша НДР и даље оправдавала епитет читалачке нације, јер је $47 \%$ становништва старијег од 14 година изјавило да чита књиге из задовољства, а $31 \%$ је то чинило у образовне сврхе. У бившој СРН, 37\% становништва читало је због разоноде, а $20 \%$ је то чинило због учења. ${ }^{32}$ Претходно поменуте читалачке навике су се одразиле и на посећеност библиотека, те је $46 \%$ становништва на истоку користило њихове услуге, у поређењу са 34\% на западу. ${ }^{33}$ Друга студија спроведена је 2000. године у

\footnotetext{
25 Овај податак односи се само на оне библиотеке које су имале особље са пуним и непуним радним временом.

${ }^{26}$ Kathleen A. Smith, "Collection Development in Public and University Libraries of the Former German Democratic Republic since German Unification", Libraries \& Culture 3 (Summer 2001): 416, http://search.ebscohost.com.proxy.kobson.nb.rs:2048/login.aspx?direct=true \&db=edsg|r\&AN=edsgcl.119025411\&site=eds-live (preuzeto 12. 2. 2017).

${ }^{29}$ У укупан број укључене су све библиотеке које су оснивале савезне државе, општине и јавне фондације. Библиотеке католичких и протестантских цркава, као и јавне библиотеке које су оснивале приватне организације, а било их је скоро 6000, нису укључене у податак.

${ }^{30}$ Kathleen A. Smith, "Collection Development in Public and University Libraries of the Former German Democratic Republic since German Unification", Libraries \& Culture 3 (Summer 2001): 416, http://search.ebscohost.com.proxy.kobson.nb.rs:2048/login.aspx?di-

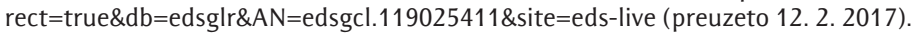

${ }^{31}$ Ibid.: 417.

32 Подаци преузети из Ulla Wimmer and Michael Seadle, "A Friendly Conquest: German Libraries after the Fall of the Berlin Wall in 1989", Library Trends 2 (2014): 207, http://search.ebscohost.com.proxy.kobson.nb.rs:2048/login.aspx?direct=true\&db=edsgao\&AN=edsgcl.404353091\&site=eds-live (preuzeto 25. 10. 2016).

${ }^{33}$ Ibid.
} 
време експанзије рачунара и тада се дошло до података да је 30\% становништва у некадашњој НДР посећивало библиотеке, у поређењу са $26 \%$ на западу Немачке. ${ }^{34}$ Јасно се види да је посећеност опала и готово се изједначила. Коначно, трећа студија спроведена је 2008. године и овом приликом истраживања су се односила на целу Немачку, без поређења истока и запада, и дошло се до података да је библиотеке користило 19\% становништва, а њих 16\% је читало књиге из забаве или ради учења. ${ }^{35}$

Академске библиотеке у бившој СРН уживале су приоритет из културних и економских разлога. Немци су били окренути образовању и стварању стручњака који би се бавили развојем економије и производње и тиме јачали државу. У том смислу, јавне библиотеке су биле синоним за низак ниво културе, што их је у очима народа представљало неозбиљним и непотребниим установама у којима се губи време. Међутим, јавне библиотеке у Немачкој су са пажљиво бираним фондовима белетристике, стручне и дечје литературе, успеле да оправдају своју улогу у менталном и духовном развоју својих корисника.

Немачка библиотека у Франкфурту на Мајни и Немачка библиотека у Лајпцигу уједињене су тако да формално образују једну институцију. Одлучено је да обе библиотеке наставе са прикупљањем немачког културног наслеђа, али само оног које је објављено на њиховом географском подручју. Немачка државна библиотека ${ }^{36}$ и Државна библиотека - Пруско културно наслеђе ${ }^{37}$ су обједињене под једним називом - Државна библиотека - Пруско културно наслеђе у Берлину и формално представљају једну иституцију, иако су физички раздвојене. Одлучено је да библиотека која је била у Источном Берлину прикупља све радове објављене пре 1945. године, а да библиотека у Западном Берлину прикупља новије наслове.

На састанку одржаном у априлу 1990. године у Берлину представљене су препоруке за развој библиотечког система обједињене Немачке. Подразумевао се развој могућности свих библиотека да обезбеде бесплатан приступ за учење, истраживање и различите врсте обука. Препоручено је и промовисање константног усавршавања и надограђивања библиотека, као и прикупљања грађе на свим медијима. Библиотеке на западу државе морале су да сарађују са онима на истоку како би се у свим подједнако обезбедиле квалитетне услуге и литература. Библиотекама које су претходно биле на границама НДР и СРН морала се пружити посебна подршка јер су се због уједињења нашле пред огромним бројем корисника са истока земље.

Након уједињења Немачке уследиле су неодложне промене у библиотекарству које је постојало у некадашњој НДР. Први корак је био преуређење библиотечких фондова на истоку новонастале државе, јер се од 40 до 45\% колекција показало незанимљивим, неадекватним и застарелим. Проценат неактуелних колекција био је много већи у академским библиотекама. Разлог ове појаве је у томе што су библиотеке у НДР проводиле деценије у интелектуалној изолацији коју су наметале источнонемачке власти које су се изричито опирале прикупљању публикација објављених на западу. Овакав вид интелектуалне цензуре довео је до тога да НДР буде у заостатку од 30 година када је у питању наука и научна литература. Многе публикације из одређених научних дисциплина нису биле замењене у библиотекама још од 1933. године. На основу тога се од 85 до 90\% публикација у универзитетским библиотекама показало као потпуно неадекватно за савремена истраживања. У 1989. и 1990. години академске библиотеке у бившој НДР изгубиле су више од половине својих корисника који су почели да користе библиотеке у СРН. Неке библиотеке у бившој СРН бележиле су свакога дана по 500 нових чланова, а становници бивше НДР су сатима мирно чекали у редовима за регистрацију, да би потом „опустошили" полице.

\footnotetext{
${ }^{34}$ Ibid.

35 Ibid.: 208.

${ }^{36}$ Ова библиотека је до уједињења била у Источном Берлину.

${ }^{37}$ Налазила се у Западном Берлину од 1968. године.
} 
Толико неадекватних публикација у библиотекама на истоку довело је до њиховог масовног затварања, те је број библиотека у НДР „смањен за 30\%". ${ }^{38}$ Библиотечка уредба из 1968. године је у тренутку уједињења истекла, па су библиотеке које су претходно биле у државном власништву враћене својим претходним власницима или су продате новим. У периоду 1988-1993. године може се приметити драстично опадање броја библиотека. У истом периоду затворено је 3700 библиотека у радним орагнизацијама 1993. године забележен је податак о 2923 затворене библиотеке, ${ }^{39}$ а неке од њих су поседовале свега једну полицу са књигама.

Други корак на путу ка интегрисању источнонемачких библиотека у модерно библиотекарство био је замена и куповина нове опреме (штампача, рачунара, читача микрофилма итд). То је, између осталог, укључило и постављање самоуслужних машина за копирање које су до тада у НДР биле сасвим непознате. Тачније, њихово коришћење у држави је било стриктно ограничено, те није било изгледа да свака библиотека поседује овај уређај. Тако убрзано осавремењивање вршило је притисак на библиотекаре у бившој НДР. Они су након уједињења морали да прихвате нове стандарде и нове начине пословања. Колики је притисак вршен на њих показује податак да су информатичку технологију поседовале само оне највеће библиотеке у НДР, те је оспособљавање за коришћење рачунара морало почети од нуле. Можда је баш то разлог зашто је у периоду 1990-1992. године број библиотекара опао за 30\%. Смањивање броја професионалног билиотечког особља није посустајало ни у наредним годинама, те је 2012. године забележено само 2900 библиотекара на истоку Немачке. ${ }^{40}$

Зграде библиотека су се након уједињења такође показале неадекватним. Биле су ненаменски саграђене, обезбеђивале су мало простора за нормално функционисање библиотека и њихових корисника и већина их је била у лошем стању. До 1998. године изграђено је 145 нових зграда за библиотеке на истоку, али неке од њих још увек чекају своје нове објекте. Библиотека војвоткиње Ане Амалије је добар пример лошег квалитета зграда у којима су биле библиотеке на истоку Немачке. Године 2004. у овој библиотеци је због лоше електричне инсталације избио пожар у коме је изгорело „50.000 публикација, а 67.000 је оштећено". ${ }^{41}$

Сарадња између библиотека такође је била на листи приоритета након уједињења. „За јавне библиотеке она се често завршавала донацијом књига, а пример је јавна библиотека у Бону која је послала 10.000 књига и 30.000 марака за куповину нових публикација јавној библиотеци у Потсдаму". ${ }^{42}$ Овај случај није усамљен, те постоји пример када је „јавна библиотека у Минхену послала 10.000 књига јавној библиотеци у Лајпцигу". ${ }^{43}$

Библиотеке су организоване по Библиотечком плану (Bibliotheksplan) донетом 1973. године у СРН. Он дефинише четири групе у које се сврставају библиотеке у зависности од свог значаја и функција. На основу овог плана не постоји једна институција која игра улогу националне библиотеке, већ ову функцију данас извршавају три установе - Национална библиотека у Лајпцигу и Франкфурту на Мајни, Државна библиотека - Пруско културно наслеђе у Берлину и Баварска државна библиотека у Минхену (Bayerische Staatsbibliothek). Према Плану, ове библиотеке, заједно са предметним библиотекама за технологију у Хановеру, медицину у Келну, економију у Килу и пољопривреду у Бону, те другим библиотекама од националног значаja, спадају у републичку групу библиотека. Оне су дужне да задовоље најзахтевније потребе

\footnotetext{
${ }^{38}$ Hermann Leskien, "Allocated Parts: The Story of Libraries in Germany", Book, Bricks and Bytes 4 (Autumn 1996): 333, http://www.jstor. org/stable/20027401 (preuzeto 12. 2. 2017).

39 Подаци преузети из Ulla Wimmer and Michael Seadle, Nav. delo: 204.

${ }^{40}$ Ibid.: 205.

${ }^{41}$ Ibid.: 209

${ }^{42}$ Mathilde V. Rovelstad, "East German Libraries in a Reunified Germany: The Adaption Process", The Journal of Academic Librarianship 3 (1992): 224, http://search.ebscohost.com.proxy.kobson.nb.rs:2048/login.aspx?direct=true\&db=aph\&AN=9705210006\&site=eds-live (preuzeto: 12. 2. 2017)

${ }^{43}$ Ibid.
} 
корисника и да садрже најсавременију и најбољу литературу. У државну групу спадају универзитетске и државне библиотеке које су матичне за све библиотеке у савезној држави. ${ }^{44}$ На територији своје савезне државе „одговорне су за стварање депозита свих објављених публикација и састављање текуће библиографије". ${ }^{45}$ Универзитетске библиотеке имају своје огранке који, по правилима Библиотечког плана из 1993. године, не би требало да поседују фонд који прелази 10.000 публикација, као ни магацин, већ би све публикације требало да буду у слободном приступу. У општинску групу спадају библиотеке у већим градовима, а у локалну се сврставају библиотеке у селима и мањим градовима чија је дужност да задовоље основне читалачке потребе локалног становништва. Библиотеке у општинској групи су дужне да поседују минимум две књиге или две јединице некњижне грађе по глави становника, те актуелну периодику. Састав њиховог фонда треба да буде разноврстан, а 20\% треба да представља некњижна грађа.

\section{Савремено немачко библиотекарство}

Децентрализовану библиотечку мрежу у Немачкој данас образује преко 11.000 библиотека у којима ради 23.000 професионалних библиотекара, заједно са још 50.000 волонтера. „Сваког радног дана библиотеке у Немачкој бележе 680.000 посета: са 205 милиона посетилаца годишње спадају у највише коришћене културне и образовне установе. Преко 10 милиона грађанки и грађана су 2010. године били активни корисници библиотеке - са позајмицом од 474 милиона медија". ${ }^{46}$ Библиотеке оснивају јавне, црквене и приватне оснивачке институције. Федерална Влада основала је Библиотеку немачког парламента (Bibliothek des Deutschen Bundestages) која је са својих 1,4 милиона јединица грађе међу највећим парламентарним библиотекама у свету, библиотеке министарстава и управних органа, библиотеке истраживачких института и друге институције од националног значаја. Међу јавне оснивачке институције сврставају се још и савезне државе, општине и јавне фондације. Католичке и протестантске цркве поседују велики број бискупских, катедралских и државних црквених библиотека где раде свештеници, научници и студенти. Ове библиотеке доступне су широј јавности, јер у многим мањим местима где не постоје јавне библиотеке управо оне чине главни извор литературе. Међу приватним институцијама које оснивају библиотеке јесу различите компаније и удружења, али и појединци који се данас ређе него у прошлости јављају као оснивачи библиотека.

Три године након уједињења објављен је извештај Библиошеке '93 (Bibliotheken '93: Strukturen-Aufgaben-Positionen $)^{47}$ који је представио планове за развој обједињеног библиотечког система. У овом документу је такође наведено да би у библиотекама требало да ради професионално особље, да финансирање мора бити у складу са потребама и одговорностима библиотека, те да план финансирања мора да важи на дуже временске стазе. Подразумева и сарадњу између различитих типова библиотека, а добра организација и менаџмент сматрају се предусловом за стварање ефикасног плана развоја сваке библиотеке. Оне морају бити способне да понуде образовање својим корисницима, али и да их науче како да се сналазе у фонду. Иако су ово наизглед једноставни захтеви, многе библиотеке у Немачкој још увек нису досегле тај ниво да испуњавају све наведене задатке.

Традиционална организација јавних библиотека још увек је на снази. Постоје централне, матичне библиотеке које поседују библиотечке огранке. Неке од јавних поседују специјалне

\footnotetext{
${ }^{44}$ Немачка је данас подељена на шеснаест савезних држава, а свака од њих поседује бар једну државну библиотеку.

${ }^{45}$ Paul Kaegbein and Diann D. Rusch, "Library and Information Science Education in West Germany", Journal of Education for Librarianship 3 (1982): 157, http://www.jstor.org/stable/40322706 (preuzeto 7. 11. 2016).

${ }^{46}$ Dagmar Girsberg, Bibliotečki sistem u Nemačkoj-pregled, prev. Maja Matić, http://www.goethe.de/ins/cs/sr/bel/kul/mag/dbs/8748191. html (preuzeto 20. 11. 2016).

${ }^{47}$ Claudia Lux, "The German Library System: structure and new developments". IFLA journal 2 (2003): 113-128, http://webdoc.sub. gwdg.de/ebook/aw/2003/ifla/vortraege/iv/ifla69/article-lux.pdf (preuzeto 7. 11. 2016).
} 
музичке библиотеке, а многе организују покретне библиотеке које у просеку могу да опслуже до 25.000 становника, а организују се у местима где нема библиотечких огранака. Постоји и посебна услуга допремања књига на кућну адресу људима са хендикепом.

Општи покрет оснивања националних библиотека у Европи није имао удела и у Немачкој коју су територијална подељеност и разнолика унутрашња политика омеле у овој мисији. Тек 1912. године основана је Немачка библиотека (Deutsche Bücherei) у Лајпцигу финансијском подршком овог града и Асоцијације за размену немачке књиге (Der Börsenverein des Deutschen Buchhandels). Након уједињења 1990. године, библиотеке у Лајпцигу и Франкфурту на Мајни ${ }^{48}$ обједињене су тако да формално чине једну институцију под називом Немачка библиотека, која је 2006. године преименована, тако да данас носи назив Немачка национална библиотека. Немачки музички архив (Deutsches Musik-archiv) основан је 1970. у Берлину, али је крајем 2010. године измештен у Националну библиотеку у Лајпцигу и данас поседује око 850.000 штампаних музикалија и преко 1,5 милиона звучних записа. Функције Немачке националне библиотеке у Лајпцигу дефинисане су актом донетим у јуну 2006. године који је предвиђао набавку, обраду, индексирање и складиштење публикација као и њихову доступност јавности. У предвиђене публикације укључени су радови објављени након 1913. године у Немачкој, потом дела објављена на немачком језику у другим земљама и коначно радови из страних земаља који су тематиком везани за Немачку. Обавезни примерак чине „две копије од сваке од 90.000 публикација које се годишње објаве у Немачкој". ${ }^{49}$ Посебна пажња придаје се делима немачких аутора објављених у периоду од 1933. до 1945. године. У Немачкој библиотеци у Лајпцигу постоји Колекција немачких аутора у егзилу (Sammlung Exil-Literatur), а у националној библиотеци у Франкфурту на Мајни Немачки архив (Deutsches Exilarchiv) у којем се налазе објављене књиге, брошуре и периодику немачких емиграната.

Библиотека у Лајпцигу дом је и Библиотеке Ане Франк (Die Anne-Frank Shoah-Bibliothek) ${ }^{50}$ чији је задатак да прикупља литературу која се односи на Холокауст над Јеврејима, али и друге радове везане за прогон људи из верских, политичких, етничих или других разлога. Музеј немачке књиге и писања (Das Deutsche Buch - und Schriftmuseum) ${ }^{51}$ као документациони центар за историју и културу књиге такође се налази у склопу Немачке библиотеке у Лајпцигу и свој дом делио је са Центром за конзервацију књига (Zentrum für Bucherhaltung) до 1998. године, када он постаје независна институција.

Државна библиотека - Пруско културно наслеђе у Берлину данас је једна од најсавременијих библиотека на свету, а посебном је чини њена мултифункционалност која започиње као складиште за 200.000 старих и ретких књига, академски и национални значај који ужива, те њена способност да савремено послује и истовремено држи до традиције. Поштовање је задобила због широког спектра наслова из различитих научних области, завидне музичке колекције и великог броја публикација из Источне Европе, Азије и Африке. Одговорна је за сакупљање културног наслеђа са територије некадашњег Пруског краљевства. ${ }^{22}$ Краљевска библиотека у Берлину (Königliche Bibliothek) основана је 1661. године, да би касније постала Пруска државна библиотека (Preußische Staatsbibliothek) која је све до Другог светског рата била најсавременија академска библиотека у Европи. Библиотека у Потсдамер улици данас је једна од најомиљенијих берлинских библиотека. Поседује 1336 читалачких места, а њен магацин простире се на девет

\footnotetext{
${ }^{48}$ Нова зграда ове библиотеке завршена је 1997. године и омогућава простор за складиштење 18 милиона публикација, тако да се процењује да ће магацин достићи пун капацитет око 2035. године.

${ }^{49}$ Claudia Lux, Nav. delo: 117.

${ }^{50}$ Ова међународна истраживачка библиотека основана је 1992. године и данас садржи приближно 16.000 књига, часописа, новина, мапа и другог материјала.

${ }^{51}$ Основан је 1884. године, што га чини најстаријим музејом књиге на свету. Поседује највећу колекцију папира са воденим жиговима.

52 Пруско краљевство постојало је од 1701. до 1918. године и обухватало је делове Пољске, Русије, Литваније, Данске и Чешке.
} 
спратова. У згради у Потсдамер улици налазе се читаонице за преглед рукописа и мапа, источноазијских рукописа и за проучавање дела и рукописа из Источне Европе. Друга зграда ове библиотеке налази се у авенији Унтер ден Линден и поседује читаонице за преглед музикалија и старих и ретких књига, а у слободном приступу има око 130.000 публикација. Обе зграде данас поседују преко 10 милиона књига, 200.000 старих и ретких књига, 4400 инкунабула, 1,8 милиона специјалних колекција штампаних радова, око 60.000 рукописа и око 2,7 милиона записа у микроформи. Такође је претплаћена на 360 новина из целог света, а електронски ресурси укључују 2836 база података са 5380 електронских часописа. Ова библиотека одговорна је и за прикупљање публикација које се односе на законодавство, литературе на словенским језицима, „штампаних радова објављених између 1871-1912, мапа објављених између 1801-1912. и штампаних музикалија објављених 1801-1945. године". ${ }^{53}$ Поседује и архив са преко 12 милиона слика.

Са око 10 милиона публикација Баварска државна библиотека у Минхену, основана 1558. године, друга је највећа научна библиотека у Немачкој. У исто време она извршава функције државне библиотеке на подручју Слободне Државе Баварске, те од 1663. године сакупља обавезни примерак са њене територије. Колекција периодике која броји преко 55.000 наслова ову библиотеку ставља на друго место по броју наслова периодике, одмах иза Британске библиотеке (British Library). Библиотека се највише фокусира на прикупљање музичких публикација, историјских радова, старе и ретке књиге, радова из источне и југоисточне Европе, као и дела са оријента и далеког Истока. Поседује највећу колекцију рукописа на свету која броји 93.000 јединица.

Постоје три Централне предметне библиотеке (Zentrale Fachbibliotheken) у Хановеру, Келну и Килу и оне су одговорне за прикупљање радова на немачком језику који се односе на технологију, економију и медицину. Техничка библиотека у Хановеру (Technische Informationbibliothek) основана је 1959. године и центар је за литературу у области технологије, архитектуре, хемије, информатике, математике и физике, а може се похвалити чињеницом да је највећа специјална библиотека на свету која прикупља литературу из претходно поменутих научних области. Претплаћена је на преко 24.600 наслова стручне периодике и има око шест милиона књига. Немачка национална медицинска библиотека (Deutsche Zentralbibliothek für Medizin) основана је 1969. године и данас се налази у Келну и Бону. Ова специјална библиотека прикупља радове из области медицине, здравства и агрономије. Са фондом од преко 1,5 милиона књига и 7300 наслова периодике она је највећа библиотека тог типа у Европи и друга највећа медицинска библиотека на свету. Немачка национална библиотека за економиjy (Deutsche Zentralbibliothek für Wirtschaftswis-senschaften - Leibniz Informationszentrum Wirtschaft) локализована у Хамбургу и Килу, највећа је специјална библиотека за економију на свету. Поседује преко четири милиона библиотечких јединица и претплаћена је на 32.000 наслова штампане и електронске периодике.

Савезна унија немачих библиотека и асоцијација (Bibliothek und Information Deutschland - BID) окупља на једном месту Немачку библиотечку асоцијацију (Deutscher Bibliotheksverband), Асоцијацију информационих и библиотечких професионалаца (Berufsverband Information Bibliothek), Асоцијацију немачких библиотекара (Verein Deutscher Bibliothekare), EKZ библиотечки сервис (ekz-bibliotheksservice $\mathrm{GmbH}$ ), Гетеов институт (Goethe Institute) и Бертелсман фондацију (Bertelsmann Stiftung). Немачка библиотечка асоцијација данас представља уједињене две асоцијације - Немачку библиотечку асоцијацију основану 1949. године у СРН (Deutscher Bibliotheksverband) и Библиотечку асоцијацију Немачке Демократске Републике (Bibliotheksverband der Deutschen Demokratischen Republik) основану 1964. године. Данас ова асоцијација броји око 2000 чланова. Могу да јој приступе све библиотеке са професионалним пословањем, државни и црквени библиотечки центри и друге институције

\footnotetext{
${ }^{53}$ Jürgen Seefeldt and Ludger Suré, Portals to the Past and to the Future: Libraries in Germany (Hildesheim: Georg Olms, 2011), 42 http:// www.goethe.de/z/pro/21-portale/portale_englisch.pdf (preuzeto 5. 11. 2016).
} 
које су у додиру са библиотекарством. Ова асоцијација фокусирана је на промоцију немачког библиотекарства и сарадњу између библиотека. Подржава научна истраживања у немачком библиотекарству, указује на важност библиотека министарствима на федералном и државном нивоу, организује курсеве за усавршавање библиотекара, ради на решавању професионалних проблема, промовише међународну сарадњу библиотека и труди се да подели савете, идеје и искуства у библиотечком пословању.

Асоцијација информационих и библиотечких професионалаца формирана је 2000. године. Данас има 6300 чланова. Фокусирана је на модернизацију, стандардизацију и развој обука за усавршавање библиотекара. Године 2006. ова асоцијација направила је базу података која окупља оне који траже посао у области библиотекарства, потенцијалне и тренутне студенте библиотекарства и библиотеке које пружају стручну праксу или траже особље.

Асоцијација немачких библиотекара основана је 1900. године и окупља професионалце и истраживаче у области библиотекарства. Данас има око 1700 чланова. Удружење се бави охрабривањем контаката између професионалних библиотекара како би унапредили и развили своје професионалне способности. Најважнија публикација коју објављује ово друштво јесте Го иишњак немачких библиошека (Jahrbuch der deutschen Bibliotheken). Ова публикација први пут је објављена 1902. године и подељена је у две секције. Прва се односи на статистичке податке који се прикупљају у академским и истраживачким библиотекама, а друга се односи на појединце који испуњавају функције чланства. Ова асоцијација одржава Конгрес библиотека (Deutscher Bibliothekartag) који је тренутно најважније професионално окупљање у Немачкој и одржава се на сваке три године, наизенично са Конгресом немачких библиотека, кога организује Савезна унија немачких библиотека и асоцијација.

Библиотечки сервис EKZ је предузеће основано 1947. године у Ројтлингену, које нуди опрему, специјално дизајниране производе за библиотеке као и консултантске услуге. Иако је од почетка фокусиран претежно на јавне библиотеке у Немачкој, у последњих неколико година представља водећи центар за снабдевање библиотека у Европи. EKZ библиотечки сервис поставио је себи циљ да увек буде на услузи библиотекама, да им испуњава све потребе и да им омогући да саме бирају потребне производе и услуге. Међу корисницима услуга овог сервиса, осим јавних библиотека, нашле су се и многе академске и истраживачке, али и Национална библиотека у Франкфурту на Мајни, где је EKZ сервис помогао у формирању слободног приступа књигама.

Гетеов институт са седиштем у Минхену, основан је 1951. године. Ова недржавна организација подржава учење немачког језика и културе, подршка је професорима немачког језика и нуди различите културне програме. Данас је овај институт једна од највећих немачких образовних и културних институција са 2800 запослених и буџетом од 334 милиона евра. Такође су у понуди и курсеви немачког језика, а сваке године има преко 23.000 полазника који материјале за учење немачког језика и упознавање немачке културе могу пронаћи у бројним библиотекама овог института. У домену библиотекарства бави се подржавањем сарадње међу библиотекама, прегледима књига и одржава професионалне конференције и обуке.

Немачки бизнисмен Рајнхард Мон 1977. године основао је Бертелсман фондацију. Залаже се за помоћ грађанима да увиде своје личне потенцијале и негује континуирани социјални развој. Фондација се фокусира на пројекте који су у области архитектуре државног образовног система и система здравствене заштите. Подржава програме, акције и развој јавниих библиотека који се односе на промовисање библиотечких колекција и читања и сарадњу библиотека са школама у образовном процесу. У сарадњи са EKZ библиотечким сервисом организовала је програм bibweb - обуку за усавршавање библиотекара преко интернета. Извештај Библиошеке 2007 направљен је у сарадњи са Савезном унијом немачих библиотека и асоцијација.

Сарадња на пољу каталогизације јесте традиција у Немачкој. Више од 100 година постоји пројекат удружене каталогизације свих инкунабула, а реализује се у Државној библиотеци у Берлину. Њено одељење за рукописе одговорно је за састављање узајамног каталога манускрипта и писама који су у поседима немачких библиотека. Каталог је назван Калиопи 
(Kalliope) и представља продукт обједињене каталогизације манускрипта и писама, а преко 30 година на овом каталогу учествовало је 450 институција са 1,2 милиона каталошких листића. Још један успешан пример узајамне каталогизације је база података периодике која обухвата милион наслова свих врста серијских публикација на свим језицима које се чувају у више од 6000 библиотека. Државна библиотека у Берлину и Национална библиотека у Франкфурту на Мајни, заједно са још 4300 институција, имале су удела у овом пројекту.

Дигитализација библиотечких колекција отпочела је скенирањем материјала високе вредности попут Гутенбергове Библије у Државној и универзитетској библиотеци у Гетингену. Баварска државна библиотека је дигитализовала најлепше рукописе, а њеним стопама пошле су и друге библиотеке које су дигитализовале своје публикације не само да би их учиниле доступним на интернету, већ и да би омогућиле њихов преглед и коришћење. Централна и државна библиотека у Берлину је завршила дигитализацију старог берлинског адресара који је обухватао период од 250 година, како би ова публикација била доступна за истраживања. Пројекат Немачка дигитална библиотека (Deutsche Digitale Bibliothek), која је највећа библиотека тог типа у земљи, започет је 2011. године и обухвата за сада преко 5,6 милиона књига, фотографија, филмова, аудиовизуелних записа, архивског материјала и репродукција слика. Њени циљеви јесу да свима понуди неограничен приступ немачком културном и научном наслеђу, затим да обједини и умрежи дигитални садржај свих немачких културних и научних институција, као и да повећа број фондова којима се може приступити са тренутних 1800 на 30.000.

Све библиотеке послују на истим принципима, али финесе које уносе у своје пословање чине их јединственим. Тако се, на пример, у Немачкој издваја библиотека Универзитета Констанц (Universitätsbibliothek Konstanz) која је отворена 24 сата дневно. Посетиоци, уколико желе и имају потребе, могу да остану у њој целу ноћ, а ову услугу реализује од априла 2001. године. Универзитетска библиотека у Триру (Universitätsbibliothek Trier) jедна је од ретких у држави које су отворене и недељом. Подстакнуте огромним приливом страних држављана, немачке јавне библиотеке пружају специјалне понуде избеглицама и тражиоцима азила како би им олакшале прилагођавање на живот у Немачкој. Јавна библиотека у Келну је 2013. године била прва у којој је отворен креативни простор. Овај програм омогућавао је корисницима да дигитализују грамофонске плоче, снимају подкастове, компонују итд. Својим бројним програмима, акцијама и креативним идејама библиотеке у Немачкој данас постављају нове стандарде, усавршавају своје пословање и нуде нове услуге такве да чак и они најмање заинтересовани за књигу могу пронаћи забаву у њима.

Библиошеке 2007 (Bibliothek 2007) је пројекат састављен удруженим снагама Савезне уније немачких библиотека и асоцијација и Бертелсман фондације. Пројекат анализира тренутно стање у немачким библиотекама и на основу тога труди се да одговори на питања попут оних који су потенцијали немачких библиотека у будућности, какву улогу ће библиотеке добити у образовном систему Немачке и какве промене треба направити како би се побољшало пословање свих библиотека у времену када је процес уједињења два библиотечка система завршен. У извештају Библиошеке 2007 представљена су и искуства и примери из библиотекарстава у Сједињеним Америчким Државама, Данској, Финској и Великој Британији. Нешто што је посебно наглашено у овој стратегији јесте да је потребно донети закон у области библиотекарства како би се, између осталог, дефинисао статус јавних библиотека. Највећи проблем код доношења закона о библиотечкој делатности јесте организационе природе. Како је Немачка подељена на шеснаест федералних држава, тако је свака од њих у потпуности слободна приликом доношења одлука у вези са културом и образовањем. Године 2010. савезна држава Тирингија је прва представила закон у области библиотекарства, а за њом су поступиле исто и државе Саксонија-Анхалт и Хесен. Међутим, ни доношењем ових закона општине нису у обавези да оснивају јавне библиотеке, те оне и даље остају под надлежношћу различитих институција. У Хамбургу школске, државне и универзитетске библиотеке су под надлежношћу градске власти за образовање, а јавне библиотеке, музеји и позоришта су одговорност градске власти за културне послове. 


\section{Закључак}

Кроз историју, Немачка је губила своје културно наслеђе, уједно и библиотеке, али је увек успевала да све губитке преброди и надокнади. Засигурно најјачи ударац за немачко библиотекарство био је Други светски рат, а пораз у њему коштао је Немце слободе и државе. Док су се у Немачкој Демократској Републици масовно градиле библиотеке чија улога је била да народу приближе социјализам, притом не водећи рачуна о квалитету зграда и фондова, у Савезној Републици Немачкој реновиране су оштећене зграде, сакупљана квалитетна литература и радило се на побољшању квалитета услуга. Немци у НДР показали су се као велики љубитељи књиге, па се увидом у статистичке податке види јасна предност у односу на Немце у СРН. У тренутку уједињења, постојао је огроман технолошки јаз између библиотека две немачке државе, толики, да је било тешко замислити да су ове библиотеке некада биле у једној држави и једнако се развијале. Упркос томе, исток земље је, захваљујући великодушности и упорности које су струјале са запада, заједно са својим библиотекама, равноправан члан многих библиотечких удружења и асоцијација, а неке од библиотека на истоку се могу похвалити изузетним резултатима у пословању и великом посећеношћу. Данас када у библиотечком пословању у Немачкој ништа више не подсећа на модел који је постојао у НДР, немачко библиотекарство је динамично и високоцењено, а својим убрзаним развојем прати савремене токове светског библиотечко-информационог система.

\section{Литература и извори:}

1. Beckers, S. "Political Culture: Differences in East and West Germany". Master's Thesis, Oregon State University, 2006. http://citeseerx.ist.psu.edu/viewdoc/download?doi=10.1.1.595.8724\&rep=rep1\&type $=$ pdf (preuzeto 17. 11. 2016).

2. Bibliotheksverband der DDR. Die Bibliotheksverordnung der Deutschen Demokratischen Republik und mit ihr in engem Zusammenhang stehende rechtliche Regelungen und Vereinbarungen. Berlin: Bibliotheksverband der Deutschen Demokratischen Republik, 1980.

3. Born, Lester K. "The Archives and Libraries of Postwar Germany". The American Historical Review 1 (1950): 34-57. http://www.jstor.org/stable/1840620 (preuzeto 10. 11. 2016).

4. Burke, Redmond. "German Librarianship from an American Angle". The Library Quarterly: Information, Community, Policy 3 (July 1952): 180-193. http://www.jstor.org/stable/4304131 (preuzeto 12. 2. 2017).

5. Chaplan, Margaret. "American Ideas in the German Public Libraries: Three Periods". The Library Quarterly: Information, Community, Policy1 (January 1971): 35-53.http://www.jstor.org/stable/4306045 (preuzeto 12. 2. 2017).

6. Chaplan, Margaret. "Public Librarianship in the Federal Republic of Germany since 1945". The Library Quarterly: Information, Community, Policy 4 (1966): 299-320. http://www.jstor.org/stable/4305693 (preuzeto 7. 11. 2016).

7. Droz, Žak. Istorija Nemačke. Zemun: Biblioteka XX veka; Beograd: Plato, 1999.

8. Girsberg, Dagmar. Bibliotečki sistem u Nemačkoj-pregled. Prev. Maja Matić. http://www.goethe.de/ins/ $\mathrm{cs} / \mathrm{sr} / \mathrm{bel} / \mathrm{kul} / \mathrm{mag} / \mathrm{dbs} / 8748191 . \mathrm{html}$ (preuzeto 20.11. 2016).

9. Kaegbein, Paul and Diann D. Rusch. "Library and Information Science Education in West Germany". Journal of Education for Librarianship 3 (1982): 154-172. http://www.jstor.org/stable/40322706 (preuzeto 7. 11. 2016).

10. Leskien, Hermann. "Allocated Parts: The Story of Libraries in Germany". Book, Bricks and Bytes 4 (Autumn 1996): 331-352. http://www.jstor.org/stable/20027401 (preuzeto 12. 2. 2017).

11. Lux, Claudia. "The German Library System: structure and new developments". IFLA journal 2 (2003): 113-128. http://webdoc.sub.gwdg.de/ebook/aw/2003/ifla/vortraege/iv/ifla69/article-lux.pdf (preuzeto 7. 11. 2016). 
12. Radulović, Marija. „Državna biblioteka u Berlinu: moderni klasik”. Glas biblioteke: časopis za savremeno bibliotekarstvo 19 (2012): 101-114. http://www.cacak-dis.rs/elektronska_izdanja/gb19/101-114Marija-Radulovic.pdf (preuzeto 18. 10. 2016).

13. Rovelstad, Mathilde V. "East German Libraries in a Reunified Germany: The Adaption Process". The Journal of Academic Librarianship 3 (1992): 221-227. http://search.ebscohost.com.proxy.kobson. nb.rs:2048/login.aspx?direct=true \&db=aph\&AN=9705210006\&site=eds-live (preuzeto 12. 2. 2017)

14. Seefeldt, Jürgen and Ludger Suré. Portals to the Past and to the Future: Libraries in Germany. Hildesheim: Georg Olms, 2011. http://www.goethe.de/z/pro/21-portale/portale_englisch.pdf (preuzeto 5. 11. 2016).

15. Smith, Kathleen A. "Collection Development in Public and University Libraries of the Former German Democratic Republic since German Unification". Libraries \& Culture 3 (Summer 2001): 413-431. http:// search.ebscohost.com.proxy.kobson.nb.rs:2048/login.aspx?direct=true\&db=edsglr\&AN=edsgcl.119025 411\&site=eds-live (preuzeto 12. 2. 2017).

16. Stieg, Margaret. "The Second World War and the Public Libraries of Nazi Germany". Journal of Contemporary History 1 (January 1992): 23-40. http://www.jstor.org/stable/260777 (preuzeto 12. 2. 2017).

17. Werner, Heinz. "The Public Libraries in East Berlin". Library Trends 1 (Summer, 1965): 21-26. https:// www.ideals.illinois.edu/bitstream/handle/2142/6230/librarytrendsv14i1e_opt.pdf?sequence=1 (preuzeto 18. 10. 2016).

18. Wiegand, Wayne A. eds. Encyclopedia of Library History. New York: Garland, 1994.

19. Wimmer, Ulla i Michael Seadle. "A Friendly Conquest: German Libraries after the Fall of the Berlin Wall in 1989". Library Trends 2 (2014): 197-211. http://search.ebscohost.com.proxy.kobson.nb.rs:2048/ login.aspx?direct=true\&db=edsgao\&AN=edsgcl.404353091\&site=eds-live (preuzeto 25. 10. 2016).

\title{
German Libraries After the Second World War: With Special Reference to the Implications of the German Reunification in 1990
}

\begin{abstract}
Summary
This paper presents the development of librarianship in Germany after the Second World War and gives an overview and synthesis of the social and professional trends thanks to which the library system of today's Germany is highly developed. It is based on a series of articles published (mostly in English) in the scientific literature over the last few decades, using comparative, historical and analytic-synthetic methods.

After the defeat in the Second World War, Germany was divided into the Federal Republic of Germany and the German Democratic Republic. Libraries in these two countries have developed under different political influences. In the Federal Republic of Germany the American model of librarianship was presented. It introduced three innovations into the world of German libraries - free access to books, reference services and democracy. At the same time, libraries in the German Democratic Republic were the weapon for educating people about the benefits of socialism. After unification of the two states in 1990, accelerated integration of the libraries from the German Democratic Republic into the modern German librarianship started immediately which included purchase and replacement of equipment, reconstruction and construction of new buildings for libraries and purchase of modern literature. Today, there are three national libraries in Germany - German National Library that is physically separated and located in Leipzig and Frankfurt am Main, Berlin State Library - Prussian Cultural Heritage in Berlin and the Bavarian State Library in Munich. The efficient and decentralized library network consists of more than 11.000 libraries.
\end{abstract}

Keywords: librarianship, Federal Republic of Germany, German Democratic Republic, national libraries, library associations, library fund, war destruction, library equipment, library buildings 